\title{
STUDI ANALISIS GAYA HIDUP KETOFASTOSIS TERHADAP RISIKO PENYAKIT TIDAK MENULAR
}

\author{
Fatimah $^{1)}$, Neli Husniawati ${ }^{2)}$ \\ Program Studi Ners Universitas MH. Thamrin \\ fatimahamitaf@gmail.com
}

\begin{abstract}
ABSTRAK
Gaya hidup ketofastosis adalah perilaku diet ketogenik yang digunakan setelah puasa (intermittent fasting).Penelitian ini bertujuan untuk mengetahui faktor-faktor yang menggambarkan gaya hidup ketofastosis. Penelitian cross sectional ini dilakukan pada 109 orang anggota grup tertutup keto-fastosis (fasting on ketosis) di salah satu media sosial. Teknik pengambilan sampel yang digunakan adalah incidental sampling. Hasil penelitian menunjukkan bahwa responden yang menjalankan gaya hidup mayoritas berusia pertengahan, berpendidikan sarjana, pekerja, tingkat penghasilan sebagian besar lebih dari UMP Provinsi DKI Jakarta, menyakini bahwa gaya hidup ini dapat menurunkan risiko penyakit tidak menular dan merasakan manfaat dari gaya hidup ketofastosis. Hal ini disebabkan karena semakin tua seseorang akan semakin sadar, melakukan deteksi, pengobatan dan kontrol penyakit.Gaya hidup ketofastosis dapat menjadi solusi hidup sehat masyarakat secara mandiri dan efektif melalui upaya promotif- preventif. Keyakinan yang besar akan gaya hidup ini dapat membuat orang yang menjalankannyamerasa lebih sehat, berat badannya turun, dan tekanan darah serta kadar gula dalam darah menurun.
\end{abstract}

Kata kunci: Gaya Hidup, Ketofastosis, Upaya Promotif-Preventif

\section{PENDAHULUAN}

Pada tahun 2017 WHO menyebutkan bahwa penyakit tidak menular (PTM) telah membunuh 40 juta orang per tahun, setara dengan $70 \%$ kematian di seluruh dunia. Setiap tahun 17 juta orang meninggal karena PTM sebelum mencapai usia 70 tahun, dan $87 \%$ kematian dini berada di negara-negara dengan pendapatan menengah ke bawah. Menurut Kemenkes RI ( 2015), kematian akibat PTM mengalami peningkatan dari 41,7\% menjadi 59,5\%. Hasil Riset Kesehatan Dasar tahun 2013 menunjukkan bahwa prevalensi PTM seperti penyakit stroke 12,1 per 1000 , penyakit jantung coroner $1,5 \%$, gagal jantung $0,3 \%$, diabetes melitus $6,9 \%$, gagal ginjal $0,2 \%$, kanker 1,4\% per tahun, dan penyakit paru kronik obstruktif 3,7\%. Perubahan gaya hidup dan kontrol kesehatan secara teratur sangat membantu menurunkan risiko PTM (Kemenkes, 2013).

Di Indonesia gaya hidup ketofastosis dikenal sejak tahun 2010 dan makin dikenal masyarakat dengan banyaknya pengguna program ini di tahun 2016. Gerakan perubahan gaya hidup dengan memodifikasi diet yang diyakini dapat membuat individu mencapai derajat kesehatan optimal ini disebut gaya hidup ketofastosis. Perilaku ketofastosis merupakan salah satu cara menjaga kesehatan dengan menggunakan diet ketogenik dan puasa (fastosis). Ketofastosis adalah gabungan dari kata diet ketogenik dan fastosis atau intermittent fasting. Mulai tahun 1920an diet ketogenik digunakan oleh dokter sebagai bagian dari pengobatan terutama pada anak dengan epilepsi yang tidak dapat berespon terhadap obat (Paoli et al., 2013). Diet ketogenik juga sering digunakan pada situasi dimana pasien yang ingin menurunkan berat badan (Paoli, 2014). Ketogenik merupakan pola makan rendah karbohidrat, tinggi lemak dan protein sedangkan fastosis sendiri adalah fasting on ketosis yang artinya puasa dalam kondisi ketosis (Prasetyo, 2016). Dalam ketofastosis, aspek yang lebih ditekankan adalah fastosis atau puasa dengan mengaplikasikannya sebagai suatu gaya hidup karena dapat mengembalikan pola hidup yang sebenarnya dengan pola makan. Puasa di beberapa literatur disebutkan sebagai intermitten fasting digunakan untuk berbagai tujuan kesehatan diantaranya untuk menurunkan berat badan (Collier, 2013). 
Menurut Aly (2014) intermittent fasting dapat memfasilitasi penurunan berat badan, mencegah terjadinya diabetes tipe 2 dan menurunkan risiko penyakit kardiovaskuler.

Prinsip dari ketofastosis adalah menciptakan kondisi ketosis yang didapat dari diet dan puasa agar tubuh menggunakan keton (degradasi lemak) sebagai sumber energi untuk menggantikan glukosa (Prasetyo, 2016). Diyakini bahwa kadar glukosa yang tinggi di dalam darah dapat memicu tingginya tinggi konsentrasi radikal bebas, perlengketan/karamelisasi di tubuh (glycation) dan berbagai abnormalitas/anomali lainnya. Dengan adanya perubahan dalam paradigma sehat maupun teknologi maka masyarakatpun mulai mencari cara agar terhindar dari berbagai penyakit. Perawat sebagai salah satu tenaga kesehatan ikut serta dalam meningkatkan kesadaran masyarakat dalam pencegahan penyakit kronik secara individu, keluarga, kelompok atau tingkat aggregate dengan mengajarkan klien tentang penyakit, peningkatan kualitas hidup dan menghindari kebiasaan yang tidak sehat (Allender, Rector \& Warner, 2014).

Beberapa penelitian tentang diet ketogenik dan intermittent fasting terkait penyakit diabetes dan kanker telah dilakukan di luar negeri, tetapi khusus gaya hidup ketofastosis belum ada. Sehingga penelitian ini dilakukan untuk mengetahui faktor-faktor yang membuat seseorang memiliki gaya hidup ketofastosis.

\section{METODE}

Rancangan penelitian yang digunakan adalah penelitian deskriptif korelasi dengan pendekatan cross sectional. Pengambilan sampel menggunakan teknik incidental sampling.Sampel penelitian ini adalah anggota grup tertutup Keto-Fastosis (Fasting on Ketosis) di media sosial Facebook yang tinggal di Jakarta, Bogor, Depok, Tangerang dan Bekasi (Jabodetabek)yang berusia 15 tahun ke atas.Alat pengumpul data yang digunakan adalah kuesioner online. Teknik analisis data yang digunakan adalah analisis univariatyang digunakan untuk menjelaskan variabel usia, pendidikan, pekerjaan, tingkat pendapatan dan tingkat keyakinan responden.

\section{HASIL \& PEMBAHASAN}

Berdasarkan hasil analisis pada tabel 1 dapat dijelaskan menunjukkan bahwa usia responden terbanyak antara 41-55 tahun (40,4\%), pendidikan responden sarjana (89\%), responden bekerja $(68,8 \%)$, dan tingkat penghasilan sebagian besar lebih dari UMP Provinsi DKI Jakarta. Menurut WHO (2017) penyakit tidak menular berkaitan erat dengan faktor usia, pendidikan rendah, pendapatan rendah, kurang aktifitas, merokok, penggunaan alkohol, dan praktik diet yang tidak sehat. Pada penelitian ini menunjukkan bahwa mayoritas anggota grup adalah kelompok usia pertengahan yang berpendidikan sarjana, bekerja, berpenghasilan lebih besar dari UMP Provinsi. Hal ini sesuai dengan penelitian yang dilakukan oleh Jiang, Liu, Ru, Zhang, Wu, dan Whang (2014) bahwa semakin tua seseorang maka akan semakin meningkat kesadarannya, melakukan deteksi, pengobatan dan kontrol hipertensi sebagai salah satu penyakit tidak menular.

Hasil penelitian tentang distribusi karakteristik responden anggota grup Keto-Fastosis (Fasting on Ketosis) dapat diketahui pada tabel 1 berikut ini: 
Tabel 1

Distribusi frekuensi berdasarkan usia, pendidikan, pekerjaan dan tingkat penghasilan anggota grup ketofastosis (fasting on ketosis) Jabodetabek $(n=109)$

\begin{tabular}{lcc}
\hline \multicolumn{1}{c}{$\begin{array}{c}\text { Karakteristik } \\
\text { demografi }\end{array}$} & Jumlah & Persentase (\%) \\
\hline Usia & 10 & 9,2 \\
- $\quad 20-30$ tahun & 40 & 36,6 \\
- $\quad 31-40$ tahun & 44 & 40,4 \\
- $\quad 41-50$ tahun & 15 & 13,8 \\
- $\quad 51-60$ tahun & $\mathbf{1 0 9}$ & $\mathbf{1 0 0}$ \\
\hline Total & 1 & 1 \\
Pendidikan: & 11 & 10 \\
- SMP & 97 & 89 \\
- SMA & $\mathbf{1 0 9}$ & $\mathbf{1 0 0}$ \\
- Sarjana & & 68,8 \\
\hline Total & 75 & 31,2 \\
\hline Pekerjaan: & 34 & $\mathbf{1 0 0}$ \\
- Bekerja & $\mathbf{1 0 9}$ & 86,2 \\
- Tidak Bekerja & & 13,8 \\
Total & 94 & \\
\hline Tingkat penghasilan & 15 & $\mathbf{1 0 0}$ \\
- Lebih dari UMP DKI & & \\
$\quad$ Jakarta & $\mathbf{1 0 9}$ & \\
- Kurang dari UMP & & \\
$\quad$ DKI Jakarta & & \\
\hline Total & & \\
\hline
\end{tabular}

Berdasarkan tabel 2 jumlah responden yang memiliki keyakinan terhadap gaya hidup ketofastosis untuk menurunkan risiko penyakit tidak menular sebesar 97,2\%. Hal ini sejalan dengan penelitian yang dilakukan oleh Tinsley dan La Bounty (2015) bahwa diet ketogenik dan intermittent fasting setiap hari selama 12-24 minggu terbukti dapat menurunkan berat badan, kadar lemak darah, dan kadar lemak tubuh (body fat) dan kadar kolesterol total. Efek metabolik dari puasa 8-12 jam juga seperti puasa di malam hari pada pasien dapat menurunkan beberapa biomarker metabolik seperti insulin, glukosa darah, substrat metabolik dan hormon (Patterson \& Sears, 2017). Keyakinan untuk melakukan gaya hidup sehat dapat ditingkatkan dengan mengubah sikap dan persepsi seseorang melalui peningkatan pengetahuan.

Tabel 2

Distribusi frekuensi berdasarkan keyakinan terhadap gaya hidup ketofastosis untuk menurunkan risiko penyakit tidak menular anggota grup keto-fastosis (fasting on ketosis) Jabodetabek $(n=109)$

\begin{tabular}{ccc}
\hline Keyakinan & Jumlah & Persentase (\%) \\
\hline Ya & 106 & 97,2 \\
Tidak & 3 & 2,8 \\
\hline Total & $\mathbf{1 0 9}$ & $\mathbf{1 0 0}$ \\
\hline
\end{tabular}

Tabel 3 menunjukkan jumlah responden yang menjalani gaya hidup Ketofastosis sebanyak 81,7\%. Hal ini disebabkan karena menjalankan suatu gaya hidup tidaklah sederhana tetapi diperlukan pengetahuan, sikap, keyakinan, nilai, persepsi dan motivasi seseorang maupun kelompok disamping juga berbagai keterampilan, sumber daya serta dukungan untuk melakukan perubahan perilaku. 
Tabel 3

Distribusi frekuensi anggota grup keto-fastosis (fasting on ketosis) Jabodetabek yang melakukan gaya hidup ketofastosis $(\mathbf{n}=109)$

\begin{tabular}{lcc}
\hline \multicolumn{1}{c}{ Gaya hidup ketofastosis } & Jumlah & Persentase (\%) \\
\hline Melakukan & 89 & 81,7 \\
Tidak melakukan & 20 & 18,3 \\
\hline \multicolumn{1}{c}{ Total } & $\mathbf{1 0 9}$ & $\mathbf{1 0 0}$ \\
\hline
\end{tabular}

Menurut Prasetyo (2016) Program i-KetoFast ${ }^{\text {TM }}$ dimulai dari fase pertama yaitu fase induksi yang dilakukan minimal 3 hari hingga 2 minggu atau hingga kadar gula darah puasa dibawah $80 \mathrm{mg} / \mathrm{dL}$ ) dengan melakukan diet ketogenik dan intermittent fasting 16-18 jam sehari. Fase induksi bertujuan untuk memicu tubuh beradaptasi dalam menggunakan lemak sebagai sumber metabolisme. Fase selanjutnya adalah fase konsolidasi yang dilakukan selama satu minggu hingga satu bulan. Di fase konsolidasi sayur tinggi serat yang berdaun, berbatang dan berbunga mulai dimasukkan ke dalam menu makanan diet ketogenik dalam jumlah terbatas. Intermittent fasting di fase konsolidasi bisa ditambahkan hingga 18-20 jam sehari. Fase ketiga adalah fase maintenance, yaitu fase dimana unsur buah dimasukkan ke dalam menu diet ketogenik disamping lemak dan sayuran serta intermittent fasting selama 18-24 jam sehari. Periode fase maintenace dilakukan selama program berlangsung dan menjadi gaya hidup.

Mattson, Longo, dan Harvie (2016) melakukan penelitian dengan menggunakan rat and mice yang diberikan diet Intermittent Fasting (IF) menunjukkan hasil beberapa indikator fisiologis seperti menurunnya tingkat insulin dan leptin seiring dengan meningkatnya sensitivitas insulin dan leptin; menurunkan lemak tubuh; meningkatnya level keton; menurunnya irama jantung istirahat dan tekanan darah; menurunnya inflamasi; meningkatnya ketahanan otak dan jantung terhadap stress; dan resistensi diabetes meningkat. Watson (2018) menyebutkan bahwa fasting merupakan salah satu strategi nonfarmakologi untuk menghadapi berbagai penyakit kehidupan modern seperti penyakit kardiovaskuler,kanker hingga diabetes dan penurunan kognitif. Sedangkan Lownes (2017) menyebutkan bahwa dari beberapa penelitian menyatakan regimen intermittent fasting merupakan regimen paling efektif dan dapat dijadikan perilaku gaya hidup sehat dengan berpuasa paling sedikit 14 jam mulai dari makan malam terakhir hingga hari berikutnya.

WHO (2018) menyebutkan jalan terbaik untuk mengontrol PTM adalah dengan berfokus pada penurunan faktor risiko yang berhubungan dengan penyakit ini.Dibutuhkan solusi dengan rendah biaya bagi pemerintah dan pemangku kebijakan untuk menurunkan faktor risiko yang dapat dimodifikasi. Kementerian Kesehatan RI sejak tahun 2015 telah mengeluarkan Peraturan Menteri Kesehatan Republik Indonesia Nomor 74 Tahun 2015 tentang upaya peningkatan kesehatan dan pencegahan penyakit yang bertujuan untuk mewujudkan individu dan masyarakat yang sehat tetap sehat, dan mencegah terjadinya penyakit pada individu dan masyarakat yang berisiko, sehingga tercapai individu dan masyarakat yang sehat dan produktif. Gerakan masyarakat hidup sehat (Germas) merupakan salah satu bentuk promosi kesehatan yang dicanangkan pemerintah Indonesia sejak tahun 2016.Gerakan masyarakat hidup sehat meliputi kegiatan melakukan aktifitas fisik, mengonsumsi sayur dan buah, tidak merokok, tidak mengonsumsi alkohol, memeriksa kesehatan secara rutin, membersihkan lingkungan, dan menggunakan jamban (Kemenkes RI, 2016). Pada tahap awal, kegiatan Germas hanya berfokus kepada aktifitas fisik 30 menit per hari, mengonsumsi sayur dan buah serta memeriksakan kesehatan secara rutin 
minimal 6 bulan sekali sebagai upaya deteksi dini penyakit. Hal ini dimungkinkan dilakukan pada diri sendiri dan keluarga dan tidak memerlukan biaya besar.

Masood dan Uppaluri (2018) menyebutkan bahwa sebagian besar penyakit kronis seperti diabetes, hipertensi, dan penyakit jantung terkait dengan obesitas yang biasanya merupakan akibat dari gaya hidup yang tidak sehat. Salah satu regimen diet yang terbukti efektif dalam menurunkan berat badan dengan cepat adalah diet ketogenik yang sangat rendah karbohidrat dan tinggi lemak.Diet ketogenik terdiri dari lemak tinggi, protein sedang, dan karbohidrat sangat rendah.Makronutrient diet dibagi menjeadi sekitar 55\%-60\% lemak, 30\%-35\% protein dan 5\%-10\% karbohidrat atau dalam diet 2000 kkal per hari, jumlah karbohidrat mencapai 20-50 gram per hari. Westman, Tondt, Maguire, dan Yancy (2018) menyebutkan diet ketogenik dengan asupan karbohidrat dibawah 50 gram perhari agar mencapai kondisi ketogenesis dapat digunakan untuk individu dengan obesitas dan diabetes. Hal ini diperkuat dengan diterimanya low carb diets sebagai salah satu manajemen Diabetes tipe 2 (T2D) pada orang dewasa oleh American Diabetes Association \& European Association (Kiddie, 2018).

WHO (2018) menyebutkan bahwa mengurangi free sugars pada orang dewasa untuk mengurangi risiko penyakit tidak menular. Patterson \& Sears (2017) menyarankan bahwa regimen intermittent fasting dapat dijadikan pendekatan untuk menurunkan berat badan dan meningkatkan kesehatan seseorang.Walaupun membutuhkan penelitian klinis dan ilmiah agar dapat digunakan sebagai salah satu pendekatan nonfarmakologi untuk meningkatkan kesehatan masyarakat.Greenberg and Deckelbaum (2016) menyebutkan bahwa kesehatan masyarakat perlu mengembangkan kapasitas dan kemauan untuk berpartisipasi dalam pembentukan kebijakan publik yang berhubungan dengan kesehatan.Kesempatan untuk membicarakan faktor-faktor risiko PTM yang dapat dimodifikasi seperti diet melalui kebijakan publik, seperti mitra swasta merupakan tantangan yang menarik.Perilaku gaya hidup ketofastosis dapat menjadi salah satu cara untuk menurunkan angka kejadian penyakit tidak menular di Indonesia. Sesuai dengan tujuan Germas untuk menurunkan beban penyakit melalui upaya promotif-preventif tanpa mengesampingkan upaya kuratif-rehabilitatif dengan melibatkan semua komponen bangsa dalam memasyarakatkan paradigma sehat (Kemenkes, 2016).

\section{KESIMPULAN DAN REKOMENDASI}

Sebagian besar responden meyakini bahwa gaya hidup ketofastosis dapat menurunkan risiko penyakit tidak menular. Hal ini dikarenakan dari berbagai penelitian diketahui bahwa intermittent fasting dan diet

ketogenik di dalam gaya hidup ketofastosis memiliki efek yang efektif terhadap penyakit tidak menular dengan menurunkan kadar insulin dan leptin, maupun body fat dan lain-lain melalui fasting atau minimal 14 jam dan memakan karbohidrat 20-50 gram per hari. Gaya hidup ini sesuai dengan program Germas dari Pemerintah Indonesia untuk menurunkan beban penyakit khususnya PTM melalui upaya promotif dan preventif.

\section{UCAPAN TERIMA KASIH}

Terima kasih kepada Kemenristek Dikti yang telah mendanai penelitian dosen pemula (PDP) ini. 


\section{REFERENSI}

1. Allender, J.A., Rector, C., \&Warner, K.D. (2014).Community Health Nursing: Promoting the Public's Health $8^{\text {th }}$ edition. Philadelpia: Lippincott Williams \& Wilkins

2. Aly, S.M. ( 2014). Role of Intermittent Fasting on Improving Health and Reducing Diseases.Int J Health Sci (Qassim), 8(3): V-VI.

3. Collier, R. (2013). Intermittent fasting: the science of going without. CMAJ, 185(9), E363-4.doi: 10.1503/cmaj.109-4451.

4. Greenberg, H. and Deckelbaum(2016). Chapter 2.3: Diet and Non-Communicable Diseases: An urgent need for new paradigms. Diakses dari https://www.karger.com/Article/PDF/452379

5. Jiang, Liu, Ru, Zhang, Wu, \& Wang. (2014). Hypertension Detection, Management, Control and Associated Factors Among Residents Accesing Community Health Services in Beijing. Scientific Reports4845(4). doi: 10.1038/srep04845.

6. Kementerian Kesehatan Indonesia. (2013). Riset Kesehatan Dasar. Jakarta: Kementerian Kesehatan RI

7. Kementerian Kesehatan Indonesia. (2015). Peraturan menteri kesehatan Republik Indonesia Nomor 74 Tahun 2015 tentang Upaya peningkatan kesehatan dan pencegahan penyakit. Jakarta: Kementerian Kesehatan Indonesia.

8. Kementerian Kesehatan Indonesia. (2016). Pemerintah canangkan Gerakan Masyarakat Hidup Sehat (GERMAS). Diakses dari http://www.depkes.go.id/article/view/16111600003/pemerintah-canangkangerakan-masyarakat-hidup-sehat-germas-.html

9. Kiddie, J. (2018).American Diabetes Association \& European Association Aprrove Low Carb Diets. Diakses darihttps://www.lchf-rd.com/2018/10/07/american-diabetes-association-europeanassociation-approve-low-carb-diets

10. Lownes, A. (2017). Intermittent Fasting. Diakses dari https://sph.umich.edu/pursuit/2017posts/intermittent-fasting.html

11. Masood W. and Uppaluri, K.(2018). Ketogenic Diet. Akses dari https://www.ncbi.nlm.nih.gov/books/NBK4999830

12. Mattson MP, Longo VD, and Harvie M. (2016).Impact of Intermittent Fasting on Health and Disease Processes.Ageing Res Rev.13.pii: S1568-1637(16)30251-3.doi: 10.1016/j.arr.2016.10.005. [Epub ahead of print] Review. PMID: 27810402.

13. Paoli, A. et al. (2013). Ketosis, ketogenic diet and food intake control: a complex relationship.

14. Frontiers psychology vol 6.published: 02February2015. doi: 10.3389/fpsyg.2015.0002

15. Paoli, A. (2014). Ketogenic diet for obesity: friend or foe?.Int. J. Environ. Res. Public Health 2014, 11, 2092-2107. doi:10.3390/ijerph110202092.

16. Patterson, R.E and Sears, D.D. (2017).Metabolic effects of intermittent Fasting.Annual Review of nutrition Vol. 37:371-393.doi.org/10.1146/annurev-nutr-071816-064634.

17. Prasetyo, N. (2016). Protokol Ketofastosis. Diakses dari http://www.ketofastosis.com/fastosis-faq 
18. Tinsley GM \& La Bounty PM. (2015).Effects of intermittent fasting on body composition and clinical health markers in human.Nutr Rev. 73(10):661-74. doi: 10.1093/nutrit/nuv041.

19. Watson, J. (2018). Hungry for Health: Fasting's medical benefits. Diakses dari https://www.medscape.com/viewarticle/898953

20. Westman, EC., Tondt, J., Maguire, E., dan Yancy, WS Jr. (2018).Implementing a low carbohydrate, ketogenic diet to manage type 2 diabetes mellitus.Expert Rev Endocrinol Metab. 13(5):263272.doi:10.1080/17446651.2018.1523713. PMID 30289048.

21. World Health Organization. (2017). Fact sheet: Noncommunicable Disease. Geneva:World Health Organization.

22. World Health Organization.(2018). Reducing free sugars intake in adults to reduce the risk of noncommunicable diseases. Diakses darihttps://www.who.int/elena/titles/free-sugars-adults-ncds/en/

23. World Health Organization.(2018). Non Communicable Diseases. Diakses dari https://www.who.int/news-room/fact-sheets/detail/noncommunicable-diseases 